\title{
17 YEARS OF SERVICE-DOMINANT LOGIC: VARGO AND LUSCH'S CONTRIBUTIONS
}

\author{
Alexander Joseph Ibnu WIBOWO 1 1, $4^{*}$, Ujang SUMARWAN² ${ }^{2}$ Budi SUHARJO ${ }^{3}$, \\ Megawati SIMANJUNTAK (D) 2 \\ ${ }^{1}$ School of Business, IPB University, Jl. Raya Pajajaran, Bogor, Indonesia \\ ${ }^{2}$ Department of Family and Consumer Sciences, Faculty of Human Ecology, IPB University, \\ GMSK Building Floor 2, IPB Dramaga Campus, Bogor, Indonesia \\ ${ }^{3}$ Department of Mathematics, Faculty of Mathematics and Natural Sciences, \\ IPB University, Jl. Meranti, Campus IPB Dramaga Bogor, Indonesia \\ ${ }^{4}$ School of Business and Economics, Universitas Prasetiya Mulya, BSD Campus, \\ Jl. BSD Raya Utama, BSD City, Kabupaten Tangerang, Indonesia
}

Received 27 June 2020; accepted 23 March 2021

\begin{abstract}
This article aims to examine the contribution of Vargo and Lusch (V\&L) to service-dominant logic (S-D logic) thinking from the first time it appeared until now. No previous study has specifically analyzed all contributions of V\&L since the phenomenon appearance of their article about this perspective in 2004. We identified a total of 146 titles of scientific publications by V\&L with other authors on the S-D logic perspective over a period of 17 years (2004-2020). Each publication was analyzed through content analysis in several key aspects. This study found that the types of publications were dominated by journal articles and book chapters. There are 95 names of authors who have collaborated with V\&L, mostly from the Americas and Europe. Based on the organization of origin of the researcher, 64 organizations have collaborated with V\&L. All V\&L publications are spread across 44 scientific journals, which include marketing and non-marketing journals or those from other social sciences. As a novelty, this study succeeds in explaining the evolution of S-D logic research over time based on V\&L works through a systematic investigation. In this study, V\&L's efforts to institutionalize S-D logic can be traced.
\end{abstract}

Keywords: service-dominant logic, marketing theory, marketing, content analysis.

JEL Classification: D83, L83, L86, M31, Z32, Z33.

\section{Introduction}

The world in which we live is complex and dynamic (Vargo et al., 2017b). However, traditional theories have ignored this extraordinary complexity of human nature (Hirschman, 1984). Traditional marketing, for example, inherits the exchange model of neoclassical economics, which has a dominant logic - the so-called goods-dominant logic (G-D logic) - found on the reciprocation of "goods." In the past few decades, current logic or point of view has surfaced that concentrate on operant resources and the creation of value, namely S-D logic (Vargo \& Lusch, 2004a). Since Vargo and Lusch (2004a) published an article "Evolving to a new dominant logic for marketing" in the JM, this logical view has developed rapidly. In the past two decades, research about this new logic has made substantial progress. The article mentioned above has cited more than 16,000 quotations. At present, this perspective builds upon 11 foundational premises (Vargo \& Lusch, 2016). S-D logic continues to evolve towards cohesive and more specific general theories, which can be empirically tested and practically applicable, and have an expanded influence on various disciplines and research streams (Vargo \& Lusch, 2017; Hastari et al., 2020).

As a "work in progress" (Vargo \& Lusch, 2006), S-D logic has become another way of considering an exchange (Vargo \& Lusch, 2004a). S-D logic admits the point of service as the foundation of all transactions (Vargo \& Lusch, 2004a, 2008a). In essence, this logic is a possible way of thinking to the traditional mindset. Traditional or G-D logic considers the physical products as the basis of exchange, while the service-dominant logic believes that

*Corresponding author. E-mail: ibnu.wibowo@pmbs.ac.id 
the foundation of exchange is service (Koskela-Huotari \& Vargo, 2018). Although starting with marketing, S-D logic increasingly represents an interdisciplinary effort (Vargo et al., 2017a; Lusch et al., 2016). Much work remains to be done in reconciling S-D logic with institutional frameworks (Vargo \& Lusch, 2016).

The existence of this new logic provides hope for future marketing theory and practice. However, S-D logic is still a very young theoretical framework (Vargo, 2018). This logic yet in its early period of existence, but has evolved out of a structure over a near-theory status thing (Vargo et al., 2017c) with the research agenda sometimes relatively abstract (Vargo et al., 2017c). Likewise, the relationship of this perspective with the conventional service framework has not been examined through empirical observation (Wilden et al., 2017). The challenge of S-D logic research going forward is to become closer to everyday language and practitioners' expression with analytical levels on systemic and empirical phenomenon (Vargo et al., 2017c).

The goal of this paper is to systematically examine research on service-dominant logic by V\&L from 2004 to the present (the past 17 years). The investigation was encouraged by the necessity to learn how S-D logic inquiry from V\&L developed and grew. This analysis reveals changes in the number and type of publications, names of authors who have collaborated, research organizations, journal names and ratings, types of publications, number of citations per article, number of authors per publication, country of origin of authors, type of journal articles, and number of pages per article, which underlies S-D logic research. A similar study was conducted by Wilden et al. (2017), which analyzes data of scientific writing to review the evolution of research related to S-D logic. However, Wilden et al.s (2017) study did not include all articles about co-creation.

\section{Literature review}

\section{Service-dominant logic}

Service-dominant logic integrates various fields of research and highlighted the development of a service-focused perspective of the transaction (Akaka et al., 2019). The core meaning of this is a general change in perspective (Vargo \& Lusch, 2004a). This mindset has shifted from dyads to multi-actors or systemic relationships within the ecosystem (Vargo \& Lusch, 2011, 2016). Besides, this perspective shifts focus from the network to the service ecosystem (SE) (Vargo et al., 2017c). The number of citations in the V\&L articles on S-D logic shows that this new logic has resonated well with ideas from various researchers around the world and attracted the attention of various growing disciplines (Koskela-Huotari \& Vargo, 2018). As a lens, service-dominant logic may be viewed as beyond, unifying, accommodating, and transformative (KoskelaHuotari \& Vargo, 2018).

On the other hand, several problems are inherent in the G-D logic approach, such as (i) fostering goods-centered understanding, where the real product is the great shape of the transaction (Vargo \& Lusch, 2004a, 2004b); (ii) placing companies not only at the center but usually making them the only actors responsible for the creation of value (Vargo \& Lusch, 2004a, 2011); and (iii) because of its linear view, G-D logic is preoccupied with emphasizing the importance of something of value, usually in monetary terms, when discussing the value (Vargo et al., 2008b). However, the S-D logic framework emphasizes (1) intangible resources related to tangible resources in value creation, (2) collaboration versus competition, and (3) relationships rather than transactions. As indicated in the S-D logic lens, an economic transaction is most ideal known regarding reciprocal service exchange. In other words, the purpose of the exchange is service, activities that originate from the application of special resources people do for themselves and others, not tangible products (Koskela-Huotari \& Vargo, 2018).

As explained earlier, the institutionalization of this logic into an integrated framework continues. It can be seen from the change in the basic premise and axiom since this perspective was first introduced. At present, the S-D logic perspective has five axioms (out of a total of 11 foundational premises). All these premises and axioms provide the basis for systematically understanding the point of view of service-dominant logic. In summary, all the current axioms and basic premises are outlined in Table 1.

Table 1. Premises of service-dominant logic (source: adapted from Vargo \& Lusch, 2016)

\begin{tabular}{|c|l|}
\hline $\begin{array}{c}\text { Pre- } \\
\text { mise }\end{array}$ & \multicolumn{1}{|c|}{ Statement } \\
\hline 1 & $\begin{array}{l}\text { Service is the foundation of social and economic } \\
\text { exchange (Axiom 1) }\end{array}$ \\
\hline 2 & $\begin{array}{l}\text { Indirect service masks the foundation of social and } \\
\text { economic exchange }\end{array}$ \\
\hline 3 & Tangible products are vehicles for service delivery \\
\hline 4 & $\begin{array}{l}\text { Intangible and dynamic resources are the basic origin } \\
\text { of reciprocal benefit }\end{array}$ \\
\hline 5 & $\begin{array}{l}\text { All economies (with or without tangible products) are } \\
\text { service economies, namely direct and indirect service }\end{array}$ \\
\hline 6 & $\begin{array}{l}\text { Value is co-created by multi-actors, such as producer, } \\
\text { consumer, supplier, and other actors (Axiom 2) }\end{array}$ \\
\hline 7 & $\begin{array}{l}\text { Actors cannot convey value but can create value } \\
\text { propositions }\end{array}$ \\
\hline 8 & $\begin{array}{l}\text { A service-focused mindset is essentially beneficiary } \\
\text { oriented and interactional }\end{array}$ \\
\hline 9 & $\begin{array}{l}\text { All social and economic actors integrate public, } \\
\text { private, and market-facing resources (Axiom 3) }\end{array}$ \\
\hline 10 & $\begin{array}{l}\text { Value is individually decided by the beneficiary, such } \\
\text { as producer, consumer, supplier, and other actors } \\
\text { (Axiom 4) }\end{array}$ \\
\hline 11 & $\begin{array}{l}\text { Co-creation of value is arranged through institutions } \\
\text { (norms, rules, values, rule of the game, belief, } \\
\text { cognitive models) and institutional logics (Axiom 5) }\end{array}$ \\
\hline
\end{tabular}




\section{Research method}

We conducted a content analysis to present a holistic and systematic review of V\&L S-D logic research. In particular, through Google Scholar, we looked for the titles of all V\&L publications that discuss S-D logic. This publication includes journal articles, book chapters, proceedings, books, working papers, and popular articles published from 2004 (when the article titled "Evolving ...." was released) to 2020. Several articles by V\&L that are not connected to service-dominant logic are not analyzed, such as Vargo and Lusch (2005) and Lusch (2017). A total of 146 publication titles were identified. Each subsequent paper was verified by applying content analysis (Krippendorff, 1980). This technique has been extensively employed by other scholars and offers profound results (Li \& Cavusgil, 1995; Leonidou, 1995; Leonidou et al., 1998). The contents of each paper were organized by one research assistant. To maintain consistency in analyzing data, the assistant was provided technical instruction.

Based on Leonidou et al. (2010), the compilation of data of the publication is according to specifically constructed coding, which consists of several parts: number and type of publications, authors who have collaborated with V\&L, research organizations, names and journal rankings in Schimago, type of publication, number of citations per article, number of authors per publication, country of origin of the author, type of journal article, and number of pages per article. The coder worked individually to assign the information enclosed in each of the 146 publications to an exceptional code sheet. After the coding process is completed, the element given to the coding sheet by the coder was examined to tracking reasonable variations in the evaluation. Given the Holsti strategy (1969), any coding contrasts, just as errors as well as issues that happened during the coding cycle, were talked about and settled with the assistance of administrators. Then, the information accommodated in the altered code sheet was inserted for investigation.

\section{Findings and discussion}

This part discusses the discoveries of the substance examination of V\&L's publications and those of their colleagues, both associated with service-dominant logic. These discoveries are restricted to a bibliographic examination of only a number of the above publications. This part is separated into several sub-segments, namely: number and type of publications, authors who have collaborated with V\&L, research organizations, journal names and rankings in Schimago, types of publications, number of citations per article, number of authors per publication, country of origin of the authors, type of journal article, and number of pages per article.

This study found that during the 17 years of the existence of S-D logic, V\&L, individually, together, or with other authors, produced 146 publications. On average, they published around nine publications a year. The highest number of publications produced in one year was in 2011 (15 titles). Overall, trends in the type of publication from year to year can be seen in Figure 2. Most V\&L publications are in the form of journal articles (62 percent) and book chapters (25 percent). The number of journal articles tends to increase from 2004 to 2008, then shows fluctuating trends in the following years (see Figure 1). On the other hand, V\&L published many articles in the form of book chapters between 2010 and 2014.

Most of the V\&L articles received a very large response from many other researchers in the world, including scholars in the marketing and non-marketing disciplines and even the social disciplines. This can be seen from the number of citations per article. The phenomenal article, the first publication on service-dominant logic, written by V\&L in 2004 in the JM, "Evolving ....", has received more

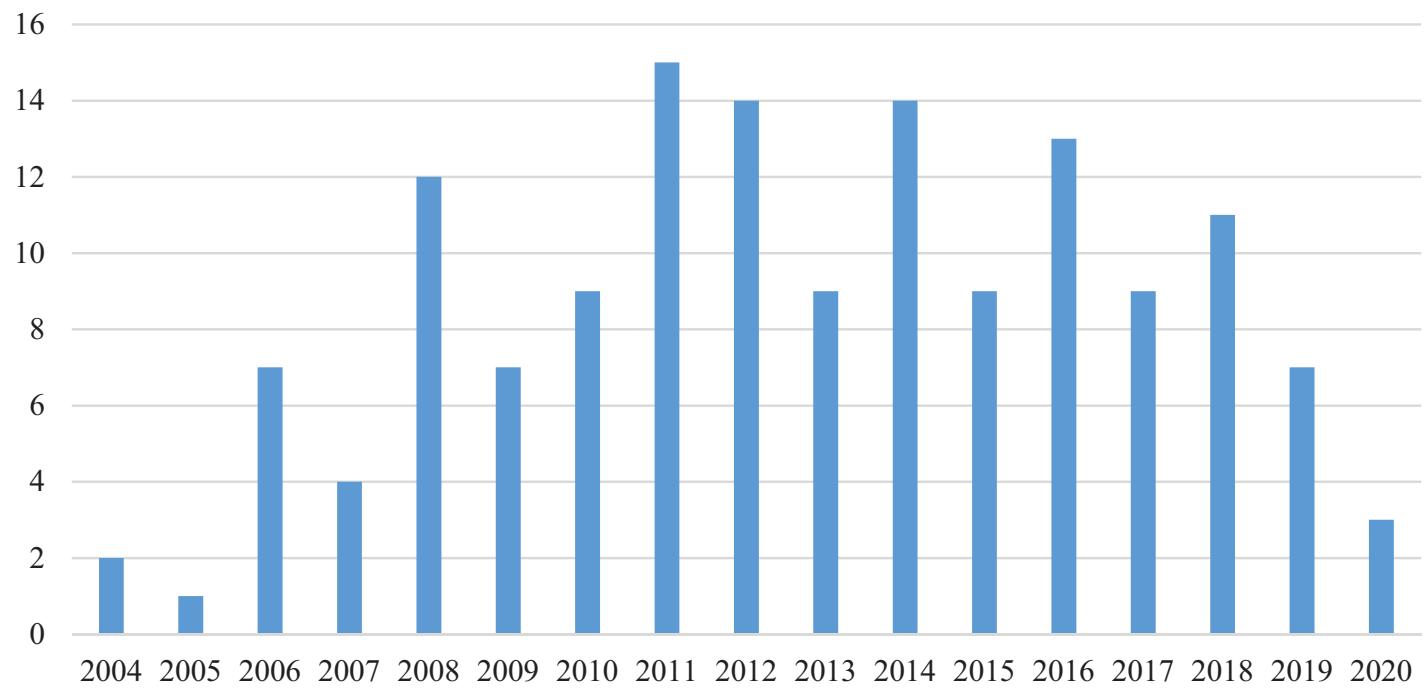

Figure 1. Number of articles published per year 
12

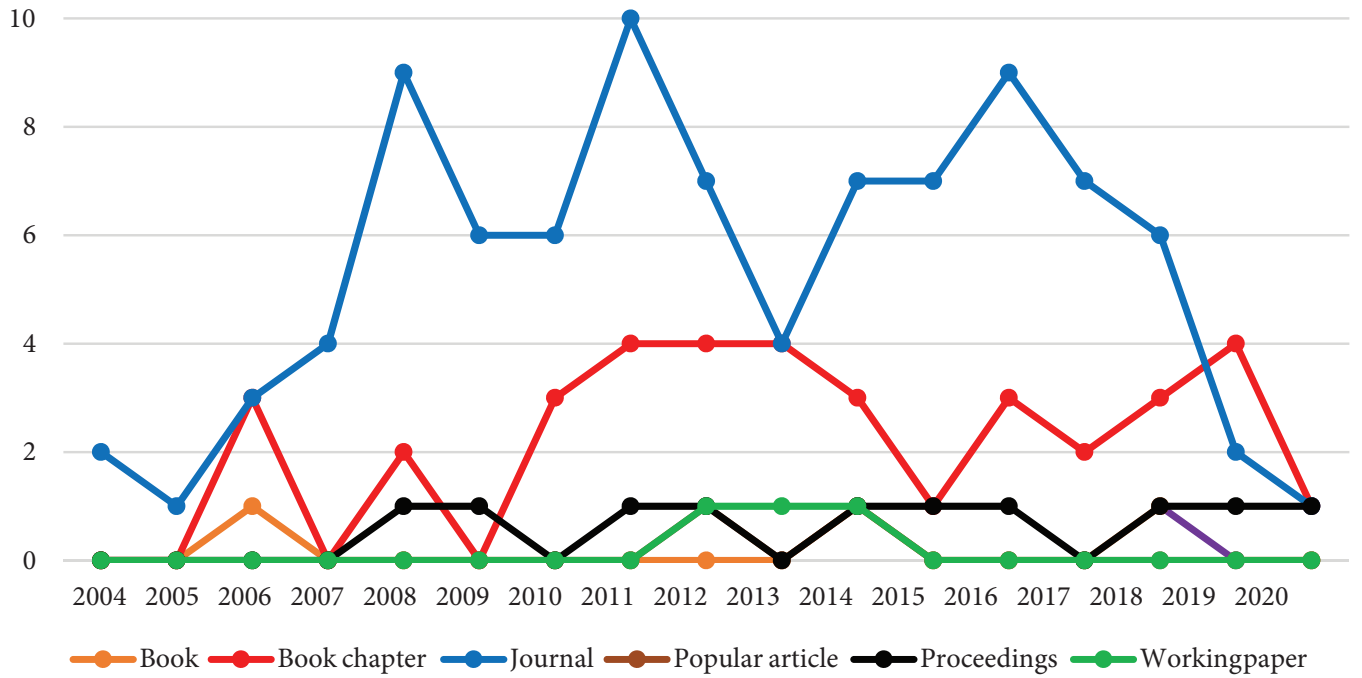

Figure 2. Types of publication per year

than 16,000 citations. Besides, the V\&L article (2008b) titled "Service-dominant logic ....," published in the JAMS has been cited by more than 7,000.

Overall, Vargo has written 120 titles, both by himself, with Lusch, and with other writers. On the other hand, Lusch wrote as many as 79 titles, both alone, with Vargo, and with other writers. Most V\&L publications were written together (56) and with three authors (50). A title with two authors can be written by Vargo with Lusch; Vargo with other writers besides Lusch; or Lusch with other writers besides Vargo. However, the collaboration between Vargo and Lusch produced the most cited work by other researchers. In his articles, Vargo also collaborated with three of his students, namely Akaka (University of Denver), Wieland (California State University), and KoskelaHuotari (Karlstad University). Interestingly, Vargo personally wrote 17 titles, while Lusch wrote only four articles. In full, the share of the number of Vargo, Lusch, and other authors' publications can be seen in Figure 3.

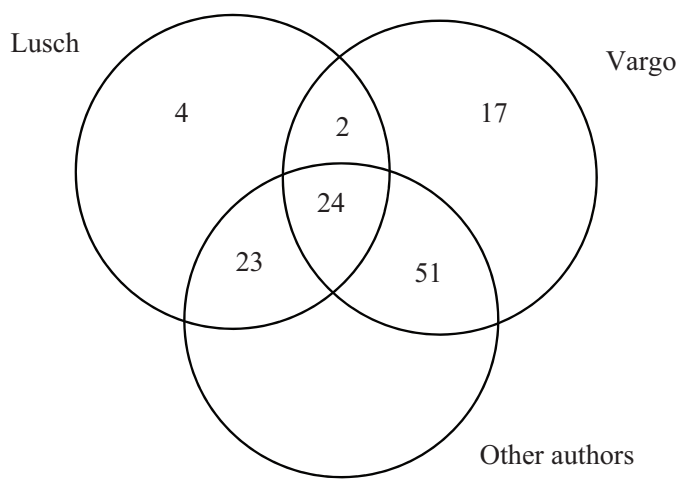

Figure 3. Share of number of publications per author
Vargo and Lusch collaborated with 95 other writers apart from each other. The three writers who collaborated most with them were Akaka (24), Wieland (11), and Koskela-Huotari (8). Furthermore, other co-authors are Spohrer (IBM) and Maglio (University of California), each with five publications. As is known, Maglio and Spohrer (2008) have pioneered the advancement of a new scientific field known as service science, the study of applying resources from at least one network to serve different networks in a transaction (Maglio et al., 2009). Other coauthors are Siltaloppi (4), Vaughan (3), Corsaro (3), Chen (3), and $\mathrm{Ng}$ (3). In full, a list of authors who have collaborated with V\&L can be seen in Appendix A.

Based on organizations where the researcher works, we found 64 organizations involved in collaboration with V\&L. The organizations that contributed the most to the publications were, of course, the University of Hawaii (129) and the University of Arizona (90), where V\&L work. Other organizations involved in collaboration were: University of Denver (23), California State University (13), Karlstad University (12), IBM Almaden Research Center (9), Texas Christian University (7), University of North Texas (5), Aalto University (4), and the University of Queensland (4). For details, the organizations to which the researchers belong can be seen in Appendix B.

Most articles are written by authors from the American region (84 percent), followed by Europe (12 percent), Australia and New Zealand (3 percent), and finally Asia (1 percent). Authors from Europe include researchers from Sweden, the UK, Finland, France, Germany, Ireland, and Norway. On the other hand, writers from Asia included researchers from Japan and China. These findings show that collaboration between V\&L and researchers, research centers, and universities from Asia, Australia, and New 
Zealand needs to develop in the future. The findings above show a gap between the number of articles written by authors in different regions of the country, such as between American and European authors. However, many papers by these American authors have been generated by a handful of American authors, the main one being Vargo, Lusch, and a number of their colleagues and PhD students, notably Akaka, Wieland, Spohrer, Maglio, Vaughan, and Chen.

$\mathrm{S}-\mathrm{D}$ logic is a new perspective in marketing theory, shifting the goods-dominant logic as the basis of exchange. This new mindset makes a significant contribution to marketing theory and even social sciences, particularly in providing a meaningful improvement to the strong institutionalized-mainstream marketing theory. That's the reason S-D logic has been difficult for mainstream marketing scholars, who are predominantly American, to accept. Therefore, in the early years of S-D logic's existence, Vargo and Lusch began to build collaborations with scholars, universities, and service centers outside America, especially Europe, in developing S-D logic.

Besides, all V\&L publications are spread across 44 scientific journals, which include journals for marketing and non-marketing disciplines and other social sciences. This dissemination supports the diffusion of S-D logic perspectives among various scientists in the world. JAMS contains the most articles (9), followed by MT (8), SS (6), IMM (4), JMM (4), and JSR (4). The complete name of the journal and the number of publications in these journals can be seen in Table 2. In addition to publication in journals, publications are carried out in the form of textbooks. To date, Vargo and Lusch have published three books, written in 2006, 2014, and 2018.

Based on the "business, management, and accounting (BMA)" field in the ranking of the Schimago, most of the V\&L articles are in the Q1 category (69 percent). Likewise, according to the "marketing" category in the Schimago journal rankings, most of the V\&L articles occupy the Q1 category (42 percent). Although several articles are not in the Q1 to Q4 categories in the BMA and "marketing" categories above, most of these articles occupy Q1 in other categories, such as manufacturing engineering, management information systems, sociology, and political science, tourism, leisure and hospitality management, transportation, information systems, and organizational behavior. This finding shows that S-D logic is accepted by non-marketing disciplines or other social sciences. Although S-D logic was born from the marketing discipline, it can also contribute to the non-marketing or other social discipline. For complete information, the ranking of Schimago-based articles can be seen in Table 3.

Table 2. Journal names

\begin{tabular}{|c|c|c|c|}
\hline Journal & Freq. & Journal & Freq. \\
\hline Journal of the Academy of Marketing Science (JAMS) & 9 & European Management Journal (EMJ) & 1 \\
\hline Marketing Theory (MT) & 8 & Georgetown Journal of Law and Public Policy (GJLPP) & 1 \\
\hline Service Science (SS) & 6 & IBM Systems Journal & 1 \\
\hline Industrial Marketing Management (IMM) & 4 & IEEE Intelligent Systems & 1 \\
\hline Journal of Macromarketing (JMM) & 4 & Innovation and Entrepreneurship in Health (IEH) & 1 \\
\hline Journal of Service Research (JSR) & 4 & International Journal of Business Environment (IJBE) & 1 \\
\hline Australasian Marketing Journal (AMJ) & 3 & $\begin{array}{l}\text { International Journal of Quality and Service Sciences } \\
\text { (IJQSS) }\end{array}$ & 1 \\
\hline European Journal of Marketing (EJM) & 3 & International Journal of Research in Marketing (IJRM) & 1 \\
\hline $\begin{array}{l}\text { International Journal of Physical Distribution and } \\
\text { Logistics Management (IJPDLM) }\end{array}$ & 3 & $\begin{array}{l}\text { International Journal of Service Science, Management, } \\
\text { Engineering, and Technology (IJSSMET) }\end{array}$ & 1 \\
\hline Journal of Business Research (JBR) & 3 & Journal of Business and Industrial Marketing (JBIM) & 1 \\
\hline Journal of Service Management (JSM) & 3 & Journal of International Marketing (JIM) & 1 \\
\hline Organizational Dynamics (OD) & 3 & Journal of Marketing Management (JMM) & 1 \\
\hline $\begin{array}{l}\text { Information Systems and e-Business Management } \\
\text { (ISBM) }\end{array}$ & 2 & Journal of Public Policy and Marketing (JPPM) & 1 \\
\hline Journal of Business Market Management (JBMM) & 2 & Journal of Retailing (JR) & 1 \\
\hline Journal of Creating Value (JCV) & 2 & Journal of Service Theory and Practice (JSTP) & 1 \\
\hline Journal of Marketing (JM) & 2 & Journal of Serviceology (JS) & 1 \\
\hline Journal of Operations Management (JOM) & 2 & Journal of Services Marketing (JSM) & 1 \\
\hline MIS Quarterly & 2 & Journal of Strategic Marketing (JSTM) & 1 \\
\hline Academy of Management Perspectives (AMP) & 1 & Journal of Supply Chain Management (JSCM) & 1 \\
\hline Academy of Marketing Science Review (AMS Review) & 1 & Marketing Management (MM) & 1 \\
\hline Brazilian Journal of Marketing (BJM) & 1 & Marketing Review St. Gallen (MRSG) & 1 \\
\hline California Management Review (CMR) & 1 & $\begin{array}{l}\text { Pacific Asia Journal of the Association for Information } \\
\text { Systems (PAJAIS) }\end{array}$ & 1 \\
\hline
\end{tabular}


Table 3. Journal ranking category in schimago 2018

\begin{tabular}{|l|c|c|c|c|}
\hline \multirow{2}{*}{ Category } & \multicolumn{2}{|c|}{ BMA* $^{*}$} & \multicolumn{2}{c|}{ Marketing } \\
\cline { 2 - 5 } & Freq. & $\%$ & Freq. & $\%$ \\
\hline Q1 & 63 & $69 \%$ & 38 & $42 \%$ \\
\hline Q2 & 10 & $11 \%$ & 15 & $16 \%$ \\
\hline Q3 & 1 & $1 \%$ & 0 & $0 \%$ \\
\hline Outside Q1-Q4 & 17 & $19 \%$ & 38 & $42 \%$ \\
\hline
\end{tabular}

Note: ${ }^{\star}$ business, management, and accounting.

Most V\&L publications are conceptual papers (96 percent), and the rest, empirical papers, only four percent (four articles). This conceptual paper places more emphasis on the theoretical study of the S-D logic perspective. As an embryo of a relatively new theory, theoretical and conceptual development of this perspective is needed to support the creation of a solid new theory, especially through various empirical studies, both qualitative and quantitative. Generally, the articles range between six to twenty pages (64 percent) and are indexed by Scopus (73 percent). Articles that are not indexed by Scopus are indexed by other agencies, such as Ebsco, Springer, and ProQuest.

Service-dominant logic as a modern approach in the marketing discipline is highlighted in every V\&L article. Therefore, it is understandable if the concept of servicedominant logic is the keyword in most V\&L articles. This becomes part of the process of institutionalization or institutional works, which corrects the traditional perspective in the discipline of marketing. Service-dominant logic is another predominant logic that views service as a process or activity of implementing operant resources possessed to provide benefits to other actors (Vargo \& Lusch, 2004a). In this framework, service is reciprocal or referred to as the service-for-service exchange. Otherwise, goods-dominant logic believes the foundational basis of exchange is the unit of output or product, both tangible (goods) and intangible (services). As stated by Vargo and Lusch (2004b), servicedominant logic does not recognize intangible products.

Another concept that is often used as a keyword for every V\&L article is value. Value is more often associated with real value, or use-value, or contextual value. The characteristic of value: phenomenological, co-created, multidimensional, and emergent (Vargo et al., 2017a). Following premise six or axiom five in the perspective of service-dominant logic, value is made jointly by many actors, and consistently includes the beneficiaries (Vargo \& Lusch, 2016). However, S-D logic also discusses exchange value (value-in-exchange), which is the value inherent in physical products. Exchange rates are measured by nominal value, namely prices (Vargo et al., 2008b). Actors can not convey use-value or real value, however, can engage in the formation of exchange value or value propositions (Vargo \& Lusch, 2016).

SE as a concept has been explored since the articles of Vargo (2009) and Lusch et al. (2010). In the view of the SE, producers, consumers, suppliers, and other actors are
Table 4. The keyword categories per article

\begin{tabular}{|l|c|c|l|c|c|}
\hline \multicolumn{1}{|c|}{ Category } & Freq. & $\%$ & \multicolumn{1}{c|}{ Category } & Freq. & $\%$ \\
\hline $\begin{array}{l}\text { Service- } \\
\text { dominant logic }\end{array}$ & 59 & $16 \%$ & Technology & 7 & $2 \%$ \\
\hline Value & 48 & $13 \%$ & $\begin{array}{l}\text { Goods-dominant } \\
\text { logic }\end{array}$ & 7 & $2 \%$ \\
\hline $\begin{array}{l}\text { Service } \\
\text { ecosystem }\end{array}$ & 36 & $10 \%$ & Brand & 6 & $2 \%$ \\
\hline Institution & 23 & $6 \%$ & Collaboration & 6 & $2 \%$ \\
\hline Resources & 23 & $6 \%$ & Strategy & 6 & $2 \%$ \\
\hline Service & 20 & $5 \%$ & Complexity & 5 & $1 \%$ \\
\hline Theory & 19 & $5 \%$ & Experience & 5 & $1 \%$ \\
\hline System & 18 & $5 \%$ & Operations & 4 & $1 \%$ \\
\hline Marketing & 17 & $5 \%$ & Effectuation & 3 & $1 \%$ \\
\hline Market & 13 & $3 \%$ & Design & 2 & $1 \%$ \\
\hline Innovation & 12 & $3 \%$ & Economics & 2 & $1 \%$ \\
\hline Relationships & 10 & $3 \%$ & Learning & 2 & $1 \%$ \\
\hline Networks & 7 & $2 \%$ & Others & 8 & $2 \%$ \\
\hline $\begin{array}{l}\text { Supply chain } \\
\text { management }\end{array}$ & 7 & $2 \%$ & & & \\
\hline
\end{tabular}

service providers and receivers or are equally generic actors (Vargo, 2009). Initially, the concept of value networks was presented as a dynamic and complex SE. However, the SE was considered better in capturing the adaptive and evolutionary nature of the value networks. SE can capture supply chains with a wider network (Lusch et al., 2010). In its development, the SE is characterized as an adaptive system of actors that integrate public, private, and market-facing resources connected by the institution and the creation of real value through reciprocal service (Vargo \& Lusch, 2016).

In institutional theory, North (1990) describes institutions as humanly conceived obstacles that form a human connection. These can be official (such as rules or laws) or informal (such as norms and conventions). Institutions comprise regulative, normative, and cognitive components, which give stableness and significance to public activity (Scott, 2013). Williamson (1999) has described the rules of the game as part of environmental institutions. Actors rely on language, institutions, and technology to regulate interactions and exchanges (Vargo \& Lusch, 2010). On the other hand, institutional arrangements are interdependent sets of institutions, which function as a set of values, cognitive models, and rules of the game that guide actors in exchanging service with other actors (Vargo \& Lusch, 2016). The details of each keyword category can be seen in Table 4 and Table 5 .

Since it was first introduced in 2004 until now, the concept of "S-D logic" has become the most mentioned keyword in every V\&L article. Specifically, this concept has always been an emphasis of V\&L articles from the first article from 2004 to 2008. In the years that followed, the number of S-D logic keywords tended to fluctuate 
Table 5. Details of keyword categories

\begin{tabular}{|c|c|}
\hline Category & Keywords \\
\hline $\begin{array}{l}\text { Service- } \\
\text { dominant logic }\end{array}$ & Service-dominant logic, Paradigms, Paradoxes, Perspective \\
\hline Value & $\begin{array}{l}\text { Value, Value co-creation, Derivative propositions, Value networks, Value proposition, Value-in-context, Exchange } \\
\text { value, Use-value }\end{array}$ \\
\hline $\begin{array}{l}\text { Service } \\
\text { ecosystem }\end{array}$ & $\begin{array}{l}\text { Service ecosystem (SE), Ecosystems theory, Ecosystems, Business ecosystems, Actor-to-Actor (A2A), Human } \\
\text { actors, Mediation, Biology, Brokerage, Ecology, Global, Stakeholders, Third-party, Triad }\end{array}$ \\
\hline Institution & $\begin{array}{l}\text { Institutions, Institutional work, Institutional theory, Institutional complexity, Context, Contract breach, Language } \\
\text { and modeling, Normative contracts, Property rights, Signs, Social construction }\end{array}$ \\
\hline Resources & $\begin{array}{l}\text { Resources, Resource theory, Resources-in-context, Resource integration, Operant resources, Human resource } \\
\text { management, Knowledge, Knowledge management, Knowledge-based view, Liquification, Absorptive capacity, } \\
\text { Collaborative process competence, Customer integration, Density }\end{array}$ \\
\hline Service & Service, Service delivery, Service models, Customer service management, Health, Health care, IT-related service \\
\hline Theory & $\begin{array}{l}\text { Theory, Theory and principles, Consumer Culture Theory (CCT), Social exchange theory, Exchange theory, } \\
\text { Exchange, Emergent, Management philosophy, History, Empirical research, Research agenda, Transdiscipline }\end{array}$ \\
\hline System & $\begin{array}{l}\text { Systems, Systems theory, Systems thinking, Viable systems approach, Complex adaptive systems, Complex } \\
\text { systems, Marketing systems, Service system, Symbol systems }\end{array}$ \\
\hline Marketing & $\begin{array}{l}\text { Marketing, Marketing concept, Marketing history, Marketing theory, General theory of marketing, Selling and } \\
\text { sales management, Service marketing, Shopper marketing }\end{array}$ \\
\hline Market & $\begin{array}{l}\text { Markets, Market formation, Market system, Market system dynamics, Markets-as-practice, Practice styles, } \\
\text { Practices, Shared understanding, General theory of the market }\end{array}$ \\
\hline Innovation & Innovation, Service innovation, Technological innovation, Transformation and innovation, Diffusion \\
\hline Relationships & $\begin{array}{l}\text { Relational view, Relationship marketing, Buyer-seller relationships, Buyer-supplier relationships, Business-to- } \\
\text { business (B2B) }\end{array}$ \\
\hline Networks & Networks, Service networks, Networking, Infomediaries \\
\hline SCM & SCM, Channels, Agility, Performance \\
\hline Technology & $\begin{array}{l}\text { Information technology, Platforms, Service-oriented IS design, Web 2.0, Customer-centric information systems } \\
\text { design, Dualities, Information system research }\end{array}$ \\
\hline $\begin{array}{l}\text { Goods- } \\
\text { dominant logic }\end{array}$ & Goods-dominant logic, Goods, Heterogeneity, Inseparability, Intangibility, Perishability \\
\hline Brand & Branding, Brand creation, Brand evolution, Brand logic, Brand value, Co-creation of brands \\
\hline Collaboration & Collaboration, Collaborative engagement, Engagement, Integration, Adaptation \\
\hline Strategy & Strategy, Corporate strategy, Strategic planning, Transition management \\
\hline Complexity & Complexity, Complexity theory, Dynamic business environment, Risk, Uncertainty \\
\hline Experience & Experience, Service experience, Customer Experience Management (CEM), Satisfaction \\
\hline Operations & Operations management, Coproduction \\
\hline Effectuation & Effectuation, Effectual logic, Effectual processes \\
\hline Design & Design Science, Design thinking, Transformative design \\
\hline Economics & Economic history, Neuroeconomics \\
\hline Learning & Learning, Expandable rationality \\
\hline Others & $\begin{array}{l}\text { Bottom of the pyramid, Education, Entrepreneurship, Magnetic resonance, Public policy, Resiliency, } \\
\text { Sustainability, United States of America }\end{array}$ \\
\hline
\end{tabular}

and decrease. On the other hand, the number of keyword "value" is highly volatile from year to year, but many are found in articles in 2008, 2011, and 2015. The keyword "service ecosystem (SE)" appears rarely from year to year, but appears more regularly in articles in 2016 and 2017. The new "institutional" keywords were widely discussed in 2011, 2015, and 2016. The "resource" keywords were used initially in 2006 and tended to fluctuate until 2016. On the other hand, "market" keywords have not been widely mentioned, but they were high in 2018. Besides, the keyword "innovation" has gained ground, especially since 2012, and even more in 2020. The full trend of keyword categories from year to year can be seen in Figure 4.

Some journal articles in collaboration with Vargo, Lusch, and other researchers have received awards. There are at least 14 articles that received awards, both from associations and journal publishers. The most phenomenal V\&L article "Evolving to a new....", released in the JM, was selected as the most-cited article and received Hunt/ Maynard Award. Next, the article titled "Service-dominant 


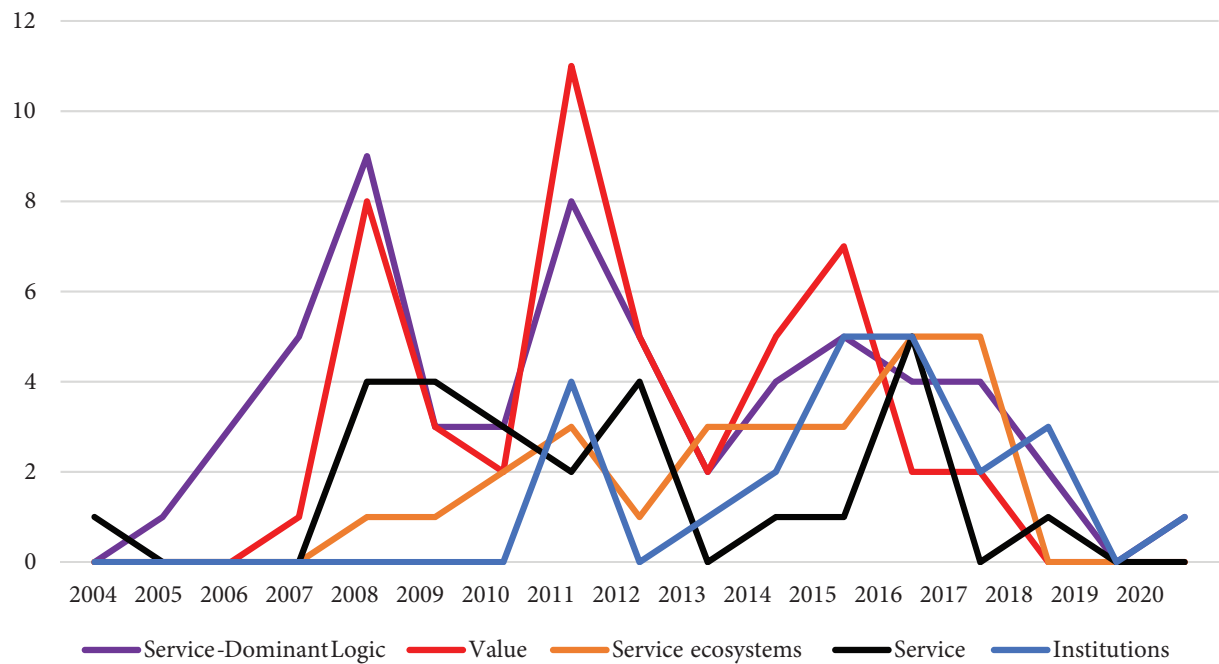

6

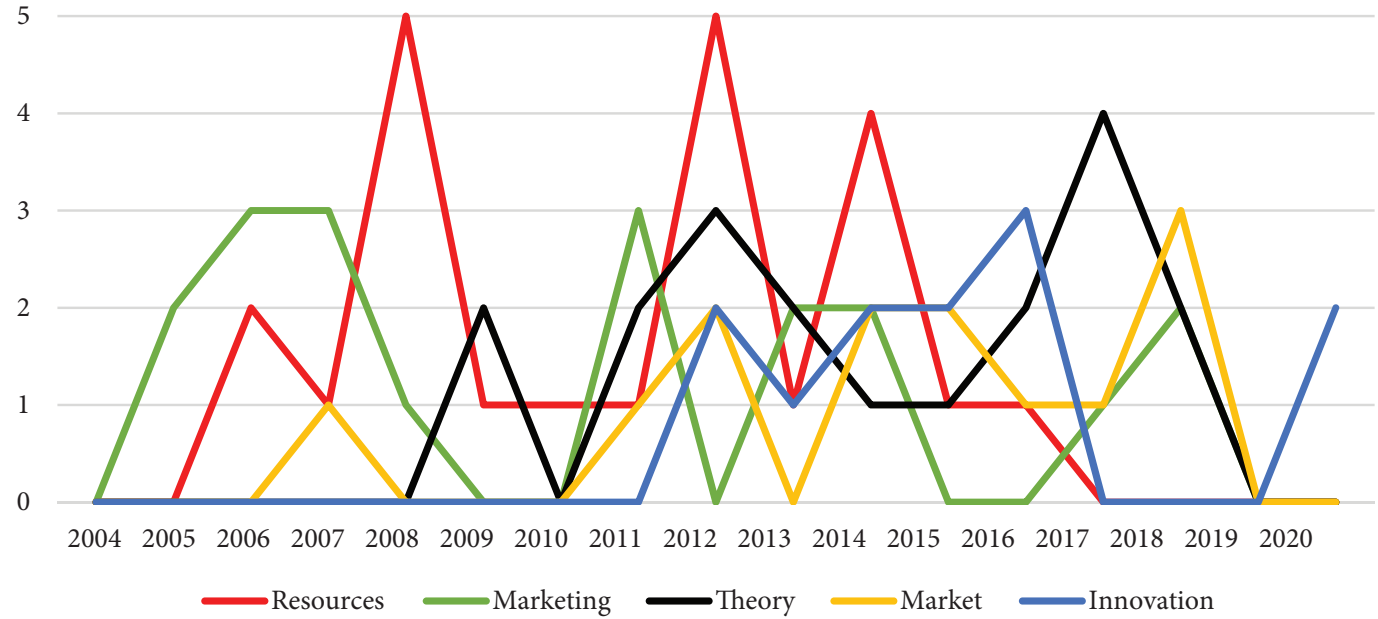

Figure 4. Keyword trends of journal articles

logic: continuing ...., published in the JAMS received an award as the most-cited article. Then, the article titled "Elevating marketing ...., published in the JAMS, received the title "The recipients of the 2014 Sheth Foundation/ JAMS Best Article Award 2013." Recently, the paper "Converging on a new ...." in the JM won the Hunt/Maynard Award.

\section{Conclusions}

This research has provided a systematic and comprehensive assessment of the works of V\&L and their colleagues about the S-D logic to date. This study intends to reveal shifts in V\&L thought, position, and efforts in the process of institutionalizing S-D logic during the 17 years of its existence. As a novelty, this finding offers useful insights for modern S-D logic and scholars who are keen on understanding the evolution of S-D logic thinking over time based on V\&L's work. In this study, V\&L's efforts to institutionalize S-D logic can be traced.
Besides, this study also guides trends related to conceptual problems and offers new knowledge as a reference for further research.

Through the content analysis method, we have been able to examine the contribution of V\&L to S-D logic thinking from the first time it emerged until now. The main conclusion of the analysis of V\&L's works is that the trend of the number of V\&L publications with other writers over 17 years tended to decline after the peak phase around 2011. The type of publication is dominated by journal articles and book chapters. Nearly 100 writers who have collaborated with V\&L are concentrated in the Americas and Europe. Besides, there are around 60 organizations that have collaborated with V\&L. All V\&L's publications have been distributed in more than 40 scientific journals, both in marketing and non-marketing disciplines, or other social sciences. The JAMS contains the most articles, followed by MT, SS, and IMM. Generally, journal articles by V\&L and their colleagues are conceptual and Scopus indexed articles. 
Apart from theoretical contributions, the findings of this study also make managerial contributions. Managers gain new perspectives for comprehending the co-creation of value. Managers understand the critical role of technology, resource integration, value proposition, markets, and strategic benefits in the value co-creation activities. Besides, actors are not only producers and consumers in a dyadic relationship but include multiple actors who serve each other by involving complex and systemic institutions and institutional arrangements. For that, each generic actor needs to focus more on the process (activity), namely service. Service is not an intangible product, but the process of implementing resources, especially operant resources, to provide benefits to other actors.

\section{Limitations}

The analysis in this study has several limitations. Our investigation did not recognize good or bad sentiments related to concepts or themes. Whereas, it can help to examine the various perspectives that shape the field. Additionally, our data set does not cover all articles by 2021 . We aim to uncover the lexicon that changed the conceptual landscape of S-D logic after some time. Therefore, this study focuses on recognizing the development of main constructs. Eventually, we consider how the reconciliation of research streams can promote S-D logic study. Other streams can combine the S-D logic approach and mainstream service theories.

\section{Future research}

As previously explained, journal articles by V\&L and their partners are conceptual. Extended empirical research in a variety of industrial contexts and disciplines can be undertaken to test this new logic. There are new concepts in this logic that have not been investigated empirically, such as value proposition, value-in-context, institutions, resource integration, business model, engagement, participation, collaboration, experience, technology, market (institutionalized solution), strategic benefits, technological innovation, and market innovation. Future studies can support the increasingly widespread development of service-dominant logic by adopting theories, such as practice theory, institutional theory, complexity theory, consumer culture theory, open innovation, emergent theory, effectuation theory, dynamic capability, SE, and system theory. Various empirical studies strengthen the existence of S-D logic towards expanded influence and the emergence of micro-level research initiatives, which can bridge theory and practice in a greater manner (Vargo et al., 2017c).

\section{References}

Akaka, M. A., Koskela-Huotari, K., \& Vargo, S. L. (2019). Further advancing service science with service-dominant logic: service ecosystems, institutions, and their implications for innovation. In P. P. Maglio, C. A. Kieliszewski, J. C. Spohrer, K. Lyons, L. Patricio, \& Y. Sawatani (Eds.), Handbook of ser- vice science (pp. 641-659). Springer.

https://doi.org/10.1007/978-3-319-98512-1_28

Hastari, R., Adela, Z., Alkhair, H., \& Wibowo, A. J. I. (2020). Direct and indirect effects of operant resources on co-creation experience: Empirical evidence from Airbnb consumers. Business: Theory and Practice, 21(1), 92-103.

https://doi.org/10.3846/btp.2020.10683

Hirschman, A. O. (1984). Against parsimony: Three easy ways of complicating some categories of economic discourse. The American Economic Review, 74(2), 89-96.

https://doi.org/10.1017/S0266267100001863

Holsti, O. R. (1969). Content analysis for the social sciences and humanities. Addison-Wesley.

Koskela-Huotari, K., \& Vargo, S. L. (2018). Why service-dominant logic? In S. L. Vargo, \& R. F. Lusch (Eds.), The SAGE handbook of service-dominant logic (pp. 40-57). Sage Publications. https://doi.org/10.4135/9781526470355.n3

Krippendorff, K. (1980). Content analysis: An introduction to its methodology. Sage.

Lawrence, T. B., \& Suddaby, R. (2006). Institutions and institutional work. In S. R. Clegg, C. Hardy, T. B. Lawrence, \& W. R. Nord (Eds.), Handbook of organization studies (2nd ed., pp. 215-254). Sage. https://doi.org/10.4135/9781848608030. $\mathrm{n} 7$

Leonidou, L. C. (1995). Empirical research on export barriers: review, assessment, and synthesis. Journal of International Marketing, 3(1), 29-43.

https://doi.org/10.1177/1069031X9500300103

Leonidou, L. C., Barnes, B. R., Spyropoulou, S., \& Katsikeas, C. S. (2010). Assessing the contribution of leading mainstream marketing journals to the international marketing discipline. International Marketing Review, 27(5), 491-518. https://doi.org/10.1108/02651331011076563

Leonidou, L. C., Katsikeas, C. S., \& Piercy, N. F. (1998). Identifying managerial influences on exporting: Past research and future directions. Journal of International Marketing, 6(2), 74-102. https://doi.org/10.1177/1069031X9800600209

Li, T., \& Cavusgil, S. T. (1995). A classification and assessment of research streams in international marketing. International Business Review, 4(3), 251-277. https://doi.org/10.1016/0969-5931(95)00009-O

Lusch, R. F. (2017). The long macro view. Journal of Macromarketing, 37(3), 321-323. https://doi.org/10.1177/0276146717712363

Lusch, R. F., \& Vargo, S. L. (2006a). Service-dominant logic: Reactions, reflections and refinements. Marketing Theory, 6(3), 281-288. https://doi.org/10.1177/1470593106066781

Lusch, R. F., \& Vargo, S. L. (2006b). The service-dominant logic of marketing: Dialog, debate, and directions. M.E. Sharpe.

Lusch, R. F., \& Vargo, S. L. (2014). Service-dominant logic: Premises, perspectives, possibilities. Cambridge University Press. https://doi.org/10.1017/CBO9781139043120

Lusch, R. F., Vargo, S. L., \& Gustafsson, A. (2016). Fostering a trans-disciplinary perspective of service ecosystems. Journal of Business Research, 69(8), 2957-2963. https://doi.org/10.1016/j.jbusres.2016.02.028

Lusch, R. F., Vargo, S. L., \& O’Brien, M. (2007). Competing through service: Insights from service-dominant logic. Journal of Retailing, 83(1), 5-18.

https://doi.org/10.1016/j.jretai.2006.10.002

Lusch, R. F., Vargo, S. L., \& Tanniru, M. (2010). Service, value networks and learning. Journal of the Academy of Marketing Science, 38, 19-31.

https://doi.org/10.1007/s11747-008-0131-z 
Maglio, P. P., Vargo, S. L., Caswell, N., Spohrer, J. (2009). The service system is the basic abstraction of service science. Information Systems and e-Business Management, 7, 395-406. https://doi.org/10.1007/s10257-008-0105-1

North, D. C. (1990). Institutions, institutional change, and economic performance. Cambridge University Press. https://doi.org/10.1017/CBO9780511808678

Scott, W. R. (2013). Institutions and organizations: Ideas and interests. Sage.

Vargo, S. L. (2009). Toward a transcending conceptualization of relationship: a service-dominant logic perspective. Journal of Business \& Industrial Marketing, 24(5/6), 373-379. https://doi.org/10.1108/08858620910966255

Vargo, S. L. (2018). Service-dominant logic: Backward and forward. In S. L. Vargo \& R. F. Lusch (Eds.), The SAGE handbook of service-dominant logic (pp. 720-739). Sage Publications. https://doi.org/10.4135/9781526470355.n41

Vargo, S. L. (2020). From promise to perspective: Reconsidering value propositions from a service-dominant logic orientation. Industrial Marketing Management, 87(3).

https://doi.org/10.1016/j.indmarman.2019.10.013

Vargo, S. L., Akaka, M. A., \& Vaughan, C. M. (2017a). Conceptualizing value: A service-ecosystem view. Journal of Creating Value, 3(2), 1-8. https://doi.org/10.1177/2394964317732861

Vargo, S. L., Koskela-Huotari, K., Baron, S., Edvardsson, B., Reynoso, J., \& Colurcio, M. (2017b). A systems perspective on markets - toward a research agenda. Journal of Business Research, 79, 260-268. https://doi.org/10.1016/j.jbusres.2017.03.011

Vargo, S. L., \& Lusch, R. F. (2017c). Service-dominant logic 2025. International Journal of Research in Marketing 34(1), 46-67. https://doi.org/10.1016/j.ijresmar.2016.11.001

Vargo, S. L., \& Lusch, R. F. (2004a). Evolving to a new dominant logic for marketing. Journal of Marketing, 68(1), 1-17. https://doi.org/10.1509/jmkg.68.1.1.24036

Vargo, S. L., \& Lusch, R. F. (2004b). The four service marketing myths: Remnants of a goods-based, manufacturing model. Journal of Service Research, 6(4), 324-335. https://doi.org/10.1177/1094670503262946

Vargo, S. L., \& Lusch, R. F. (2005). Consumers' evaluative reference scales and social judgment theory. In N. Malhotra (Eds.), Review of marketing research (Vol. 1, pp. 245-284). Emerald Group Publishing Limited. https://doi.org/10.1108/S1548-6435(2004)0000001010
Vargo, S. L., \& Lusch, R. F. (2006). Service-dominant logic: what it is, what it is not, what it might be. In R. F. Lusch \& S. L. Vargo (Eds.), The service-dominant logic of marketing: Dialog, debate, and directions (pp. 43-56). ME Sharpe.

Vargo, S. L., \& Lusch, R. F. (2008a). From goods to service(s): Divergences and convergences of logics. Industrial Marketing Management, 37(3), 254-259.

https://doi.org/10.1016/j.indmarman.2007.07.004

Vargo, S. L., \& Lusch, R. F. (2008b). Service-dominant logic: Continuing the evolution. Journal of the Academy of Marketing Science, 36(1), 1-10.

https://doi.org/10.1007/s11747-007-0069-6

Vargo, S. L., \& Lusch, R. F. (2010). From repeat patronage to value co-creation in service ecosystems: A transcending conceptualization of relationship. Journal of Business Market Management, 4(4), 169-179.

https://doi.org/10.1007/s12087-010-0046-0

Vargo, S. L., \& Lusch, R. F. (2011). It's all B2B... and beyond: Toward a systems perspective of the market. Industrial Marketing Management, 40(2), 181-187.

https://doi.org/10.1016/j.indmarman.2010.06.026

Vargo, S. L., \& Lusch, R. F. (2016). Institutions and axioms: An extension and update of service-dominant logic. Journal of the Academy of Marketing Science, 44(1), 5-23.

https://doi.org/10.1007/s11747-015-0456-3

Vargo, S. L., \& Lusch, R. F. (2018). The SAGE handbook of service-dominant logic. Sage Publications. https://doi.org/10.4135/9781526470355

Vargo, S. L., Magio, P. P., \& Akaka, M. A. (2008). On value and value co-creation: A service systems and service logic perspective. European Management Journal, 26(3), 145-152. https://doi.org/10.1016/j.emj.2008.04.003

Webster, Jr. F. E., \& Lusch, R. F. (2013). Elevating marketing: Marketing is dead! Long live marketing! Journal of the Academy of Marketing Science, 41(4), 389-399. https://doi.org/10.1007/s11747-013-0331-z

Wilden, R., Akaka, M. A., Karpen, I. O., \& Hohberger, J. (2017). The evolution and prospects of service-dominant logic: An investigation of past, present, and future research. Journal of Service Research, 20(4), 345-361.

https://doi.org/10.1177/1094670517715121

Williamson, O. E. (1999). The mechanisms of governance. Oxford, UK.

\section{APPENDIX A. AUTHORS WHO HAVE COLLABORATED WITH VARGO AND LUSCH}

\begin{tabular}{|l|c|l|c|l|c|}
\hline \multicolumn{1}{|c|}{ Authors } & Freq. & \multicolumn{1}{c|}{ Authors } & Freq. & \multicolumn{1}{c|}{ Authors } \\
\hline Melissa Archpru Akaka & 24 & Yi He & 2 & Lance A. Bettencourt & 1 \\
\hline Heiko Wieland & 11 & Zach G. Zacharia & 2 & Laura A. Smith & 1 \\
\hline Kaisa Koskela-Huotari & 8 & Zhen (Richard) Tang & 2 & Luk Van Wassenhove & 1 \\
\hline James C. Spohrer & 5 & Alan J. Malter & 1 & Maria Colurcio & 1 \\
\hline Paul P. Maglio & 5 & Anders Gustafsson & 1 & Marialuisa Saviano & 1 \\
\hline Jaakko Siltaloppi & 4 & Angeline Nariswari & 1 & Matthew M. Mars & 1 \\
\hline Claudia M. Vaughan & 3 & Anne-Laure Fayard & 1 & Michael A. Hitt & 1 \\
\hline Daniela Corsaro & 3 & Brian Sauser & 1 & Michael A. Merz & 1 \\
\hline Hong-Mei Chen & 3 & Carol Kelleher & 1 & Mikko Ketokivi & 1 \\
\hline Irene C L Ng & 3 & Chris Horbel & 1 & Mohan Tanniru & 1 \\
\hline Bo Edvardsson & 2 & Christoph Peters & Mrinal Ghosh & 1 \\
\hline
\end{tabular}


End of Appendix A

\begin{tabular}{|c|c|c|c|c|c|}
\hline Authors & Freq. & Authors & Freq. & Authors & Freq. \\
\hline Charles R. Greer & 2 & Christopher Wu & 1 & Pamela Clavier & 1 \\
\hline David R. Nowicki & 2 & Cristina Mele & 1 & Rafe Sagarin & 1 \\
\hline Elizabeth Davidson & 2 & Daniel John Flint & 1 & Ralph Badinelli & 1 \\
\hline Francesco Polese & 2 & Daniel Zeng & 1 & Robert R. Harmon & 1 \\
\hline Fred W. Morgan & 2 & David Schmidtz & 1 & Roger W. Schmenner & 1 \\
\hline Frederick E. Webster Jr & 2 & Debora Sarno & 1 & Ron Fisher & 1 \\
\hline Hope Jensen Schau & 2 & Evert Gummesson & 1 & Satish Nambisan & 1 \\
\hline Janet R. McColl-Kennedy & 2 & Frederic Ponsignon & 1 & Sergio Barile & 1 \\
\hline Javier Reynoso & 2 & G. Wessels & 1 & Stefan Michel & 1 \\
\hline Jennifer D. Chandler & 2 & Gopikrishna Deshpande & 1 & Steve Baron & 1 \\
\hline Jillian C. Sweeney & 2 & Haluk Demirkan & 1 & Sun-Young Park & 1 \\
\hline Matthew O’Brien & 2 & Helge Löbler & 1 & Terri L. Griffith & 1 \\
\hline Michael Barrett & 2 & Jaideep Prabhu & 1 & Tronvoll & 1 \\
\hline Nancy W. Nix & 2 & James R. Brown & 1 & Tuure Tuunanen & 1 \\
\hline Nathan Caswell & 2 & Jameson K. M. Watts & 1 & Valtteri Kaartemo & 1 \\
\hline Nathaniel N. Hartmann & 2 & Jeff Heyl & 1 & Wesley Bridges & 1 \\
\hline Roberta Sebastiani & 2 & Jeffrey J. Welser & 1 & Yasmin van Kasteren & 1 \\
\hline Roger S. Maull & 2 & Josina Vink & 1 & Yassi Moghaddam & 1 \\
\hline Satoru Fujita & 2 & Judith L. Bronstein & 1 & Youngjin Yoo & 1 \\
\hline Tracey S. Dagger & 2 & Keith A. Joiner & 1 & Yuri Seo & 1 \\
\hline Wesley S. Randall & 2 & Kellilynn M. Frias & 1 & & \\
\hline
\end{tabular}

\section{APPENDIX B. THE AUTHORS' ORGANIZATION}

\begin{tabular}{|c|c|c|c|c|c|}
\hline $\begin{array}{c}\text { Organization Name/ } \\
\text { University }\end{array}$ & Freq. & Organization Name/University & Freq. & Organization Name/University & Freq. \\
\hline Hawaii at Manoa & 129 & Salerno & 2 & Temple & 1 \\
\hline Arizona & 90 & Western Australia & 2 & Texas A\&M & 1 \\
\hline Denver & 23 & Auburn & 1 & Texas Tech & 1 \\
\hline California State & 13 & California Polytechnic State & 1 & $\begin{array}{l}\text { Thunderbird School of Global } \\
\text { Management }\end{array}$ & 1 \\
\hline Karlstad University & 12 & Cambridge & 1 & Cattolica di Milano & 1 \\
\hline $\begin{array}{l}\text { IBM Almaden Research } \\
\text { Center }\end{array}$ & 9 & $\begin{array}{l}\text { Domino Integrated Solutions } \\
\text { Group }\end{array}$ & 1 & College Cork & 1 \\
\hline Texas Christian & 7 & Griffith & 1 & California & 1 \\
\hline North Texas & 5 & Helsinki of Technology & 1 & Cassino & 1 \\
\hline Aalto & 4 & Indiana & 1 & Catanzaro Magna Graecia & 1 \\
\hline Queensland & 4 & $\begin{array}{l}\text { Inland Norway of Applied } \\
\text { Sciences }\end{array}$ & 1 & Leipzig & 1 \\
\hline Exeter & 3 & Insead & 1 & Liverpool Management School & 1 \\
\hline Oklahoma & 3 & Lincoln & 1 & Naples Federico II & 1 \\
\hline Warwick & 3 & Metacyber & 1 & San Francisco & 1 \\
\hline Bradley & 2 & Monash & 1 & Southern Denmark & 1 \\
\hline Catholic & 2 & New York & 1 & Tennessee & 1 \\
\hline Dartmouth & 2 & Oakland & 1 & Turku & 1 \\
\hline EGADE Business School & 2 & $\begin{array}{l}\text { Oslo School of Architecture } \\
\text { and Design }\end{array}$ & 1 & Wisconsin-Milwaukee & 1 \\
\hline Hosei & 2 & Pam Clavier Inc. & 1 & Victoria of Wellington & 1 \\
\hline Lehigh & 2 & Parthenope of Naples & 1 & West Virginia & 1 \\
\hline Cattolica del Sacro Cuore & 2 & San José State & 1 & Willamette & 1 \\
\hline Cambridge & 2 & Sapienza Rome & 1 & & \\
\hline Maryland & 2 & Stockholm & 1 & & \\
\hline
\end{tabular}

Note: ${ }^{\star}$ The organization of the researchers in each article. 